\section{1. 緒 言}

回転粘度計には外筒回転型の Freundlich の粘度計, Couette の粘度計と, 内筒回転型の Searle の粘度計, Stormer の粘度計などがあるが，一般に外筒回転型の方 が大きい速度勾配を得ることができ，液の安定性る大き い。をた，回転粘度計では Newtonian flow ばかりでな く,速度勾配を变化させることによって non Newtonian flow の测定にる便利である。しかし，これらの回転粘度 計に共通な欠点は, end effect の存在することであって このため一般には計算によってこの補正を行っている。

そこで, この end effect を粘度計の機棈上除去し, か $つ$ Newtonian flow ばかりでなく non Newtonian flow の粘性係数の測定も可能であること，また速度を広範囲

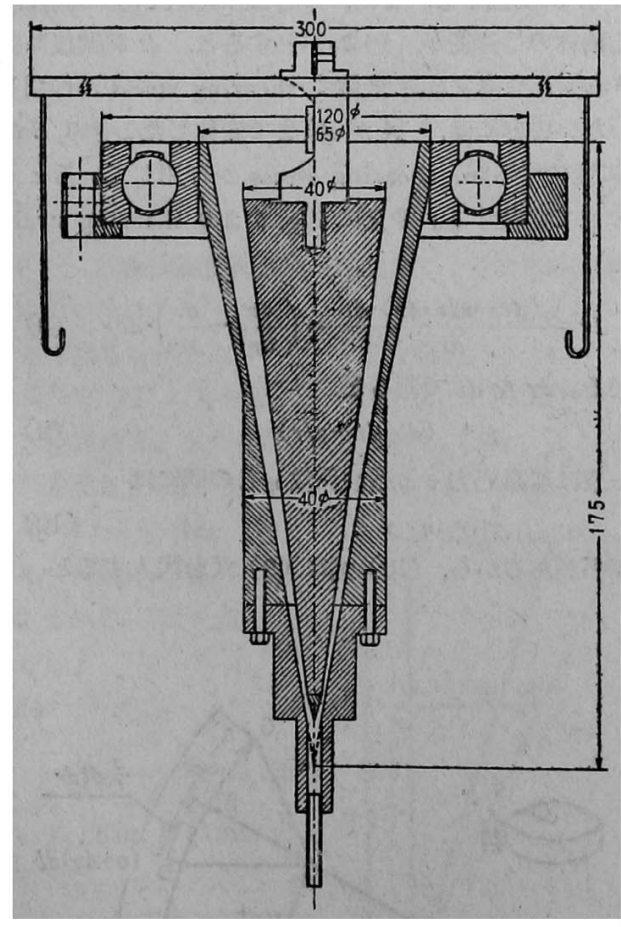

Fig. 1 Cone part of the cone type rotational viscometer
に变化させ ること、試料の注入排出の迅速容易なこと を目的とした粘度計を製作した。

end effect を除くために，同頂点円錐の外筒回転型と し，底部に試料の注入排出用の管を取りつけ，をた，速 度はギャボックスと無段変速機で広範围に変化させるよ うにした。このような新しい型の粘度計について, 理論 式と実験值との合一性, 装置の特性と精度, 粘性係数の 測定範囲などを考察した。

\section{2. 実 験 装 置}

ここに製作した円錐回転型粘度計は，その機構上，粘 度計本体，层動機構，測定器の三つに分けられる。

（1）粘度計本体：粘度計本体は Fig. 1 に示すよ らに真鍮鍀物製の二つの円錐体より成る。内錐は，上部 に鏡と balancing arm があり, torsion wire でつり下 ほられている。balancing armは, 内錐の慣性能率を变 化させて短周期振動を吸収し，測定を容易ならしめるた めに damper の働きをする錘をつり下げるためのるので ある。Fig. 2 に示すように，外錐は垂㨁に立てる必要 上. 水平調節わしをるつ鉄板台に立てた 3 本の支柱に,

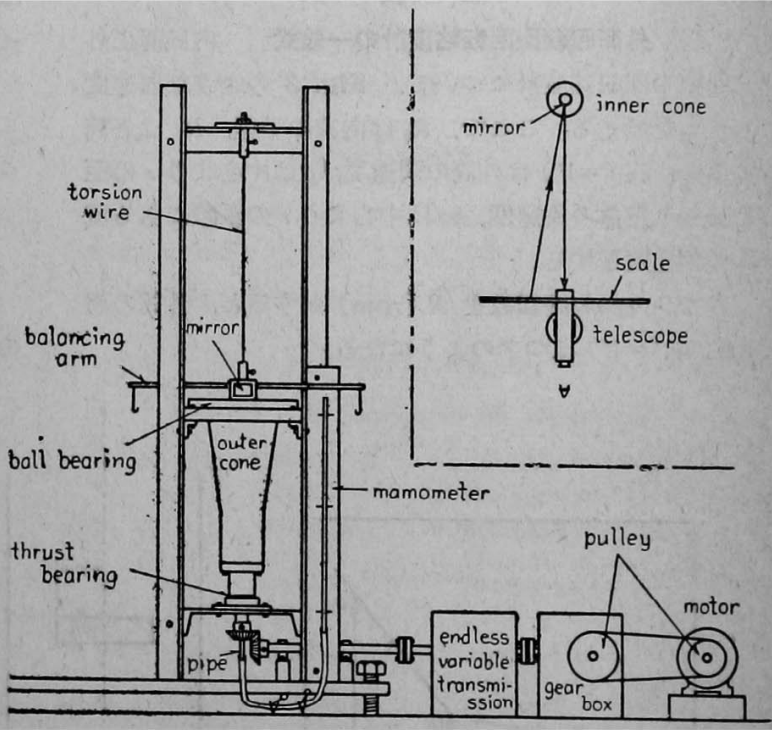

Fig. 2 Experimental apparatus

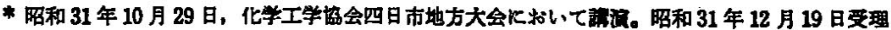

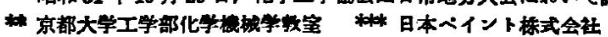


大型ベフリングと、スラストペフリングで支持されてい、 る。大型ペアリングは，外錐が回転中，应擦に上る温度 上界を生ずる結果，試料夜体の温度変化を起すことをさ けるためと，回転が円滑にいくために設けられたるので あり、スラストベフリングあ回転の円滑化を考虑して設 けられたるのである。外錐は，その底部に管を有し，こ れによって試料液体の注入排出, および液高さの測定を 行引。

内錐は 2 段に高さの加瑊できる横材より torsion wire 火よってっり下げられる。

torsion wireは，内錐と外錐が完全に同心になって接 触好㹸とをを確めるために，硬質絶緑材の円板上汉取り つけられ，湘定の際にテスターで導通を調へて接触をさ ける。内外二円錐は同頂点で, 外錐底部に排管の孔があ けられている。試料夜高さは，管から連結されたマノメ ーターで知る。この目盛は, 内錐上端と外錐下端の間の 高さを毛管現象を考虑して10 等分してある。

（2）伝動機椣 外錐の回転は，モーターの駆動を ブーリー，ギャボックス，無段变速機で 4〜200 rpm K 変速して行う。

（3）測定器 外錐の回転に上って夜体の粘性のた めに生じる内錐の㨭れは，望遠鏡に取りつけられた目盛 尺の鏡による反射像を望遠鏡によってとらえることによ って知る。

\section{3. 理 占 式}

（1）外筒回転型回轱粘度計の一般式 内筒静止外 筒回転の回転粘度計について, Fig. 3 の上5な周速度 の分布を考える。ここで， $R_{0}$ は内筒の半径， $R_{1}$ は外筒 の半径, $v_{R 1}(=V)$ は外筒の周速度, $v$ は中心より $r$ の距 離にある流体の周速度，wは中心上りrの距離にある流 体の角速度とする。

さて, 外筒の回転数を $N(\mathrm{rpm})$ とすると，外筒の周 速度 $v_{R 1}(=V)$ はつきの上ろになる。

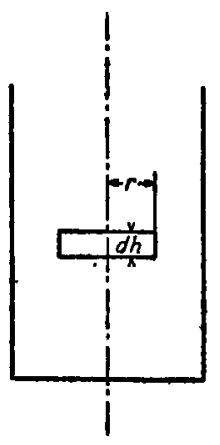

Fig. 4

$$
v_{R 1}=V=2 \pi R_{1} N / 60[\mathrm{~cm} / \mathrm{sec}]
$$

一方, 。とwの間炕师き関保が成立子る。

$$
v=r \cdot w
$$

ここにwは一定でなくrの函数として

$$
w=f(r)
$$

と表わせる。また，vのて対する傾斜を $w^{\prime}$ とすると

$$
d v / d r=w^{\prime}
$$

ここK $w^{\prime}$ は一定でなく $r$ の函数として

$$
w^{\prime}=g(r)
$$

と表わせる。

つぎ Fig. 4 の上らに, 微少位高さ $d h$, 半径 $r$ の円板を考劣る。円筒の側面作用するモーメントは， 剖断応力をてで示すとつぎのようになる。

$$
d M=(2 \pi r \cdot d h) r \cdot \tau
$$

ここでモーメントは，静止せる内筒から回転せる外筒 にいたるまで、無関係に一定であると考えると

$$
\begin{aligned}
& \tau=\frac{d M}{2 \pi \cdot d h} \cdot \frac{1}{r^{2}}=c \frac{1}{r^{2}} \\
& \text { ただし } \quad c=d M / 2 \pi \cdot d h
\end{aligned}
$$

つきに Fig. 5 に示すようと，外筒回転粘度計では， 中心よりナの距離にある周速度。の液体は, $d t$ 時間後に はv・dt K变位する。また，中心より $(r+d r)$ の距離に める液体の周速度少 $(v+d v)$ とすると， $d t$ 時間後には $(v+d v) d t$ 变位する。液体K shearing stress ていない場合には，Aが $A^{\prime}$ まで变位したときに $B$ は $B^{\prime}$ K变位するが, shearing stress が作用していると $B$ は $C$ まで变位する。ゆえに Fig. 5 より shearing strain rは

$$
d r=\frac{(d v-v / r \cdot d r) \cdot d t}{d r}=\left(\frac{d v}{d r}-\frac{D}{r}\right) \cdot d t
$$

となる。 $d r$ を $d t$ で割ると

$$
\dot{r}=(d v / d r-v / r)
$$

一般に勏断応力 $\tau$ と粘性保数 $\eta$ との間には

$$
\tau=\eta \cdot \dot{r}
$$

の関係があるから（10）式に（9）式を代入すると
Fig. 3

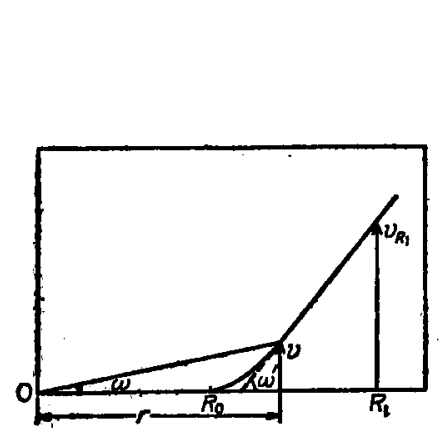

352

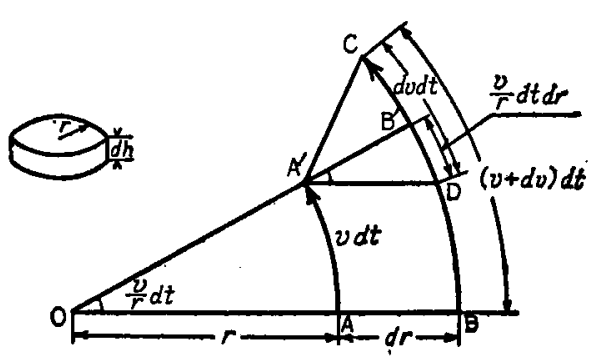

Fig. 5 


$$
=\pi \cdot(d v / d r-v / r)
$$

(7) 式と(11) 式加

$$
\tau=\eta(d v / d r-v / r)=c \cdot 1 / r^{2}
$$

ここで $c / \eta=c_{1}$ と妨くと

$$
d v / d r-v / r=c_{1} \cdot 1 / r^{2}
$$

(13) 式を变形して

$$
r-\frac{d(v / r)}{d r}=c_{1} \cdot \frac{1}{r^{2}}
$$

ゆ穴に（14）式を積分すると

$$
0=c_{2} r-c_{1} / 2 r
$$

ここに $c_{2}$ は積分常数である。いま， $r=R_{0}$ のとき $v=0$ なる初期条件を（15）式に代入すれば

$$
c_{2}=c_{1} / 2 R_{0}^{2}
$$

（16）式を（15）式代入して

$$
v=\frac{c_{1}}{2}\left\{\frac{r}{R_{0}^{2}}-\frac{1}{r}\right\}
$$

${ }^{v}=v_{R 1}(=V)$ のとき， $r=R_{1}$ であるから上式より

$$
c_{1}=\frac{2 V}{R_{1}} \cdot \frac{R_{0}{ }^{2} R_{1}{ }^{2}}{R_{1}{ }^{2}-R_{0}{ }^{2}}
$$

(18) 式を (17) 式代入して

$$
v=\frac{2 V}{R_{1}} \cdot \frac{R_{0}{ }^{2} R_{1}{ }^{2}}{R_{1}{ }^{2}-R_{0}{ }^{2}}\left\{\frac{r}{R_{0}{ }^{2}}-\frac{1}{r}\right\}
$$

ゆえに（12）式より

$$
\tau=\eta \frac{c_{1}}{\tau^{2}}=\frac{2 V \eta}{R_{1}} \cdot \frac{R_{0}{ }^{2} R_{1}{ }^{2}}{R_{1}{ }^{2}-R_{0}{ }^{2}} \cdot \frac{1}{\tau^{2}}
$$

(20）式を（7）式に代入すると

$$
d M=\frac{4 \pi V}{R_{1}} \cdot \frac{R_{0}{ }^{2} R_{1}{ }^{2}}{R_{1}{ }^{2}-R_{0}{ }^{2}} \cdot \eta \cdot d h
$$

（2）円錐回転型粘度計への適用 円錐回転型粘度 即に怙いては， $R_{0}$ を任意の高さ $h$ の内雓の半径， $R_{1}$ を 任意の高さ $h$ の外錐の半径, $h$ を任意の高さ， $\theta_{0}$ を内錐 の頂角の $1 / 2, \theta_{1}$ を外錐の頂角の $1 / 2, H$ を内錐の高さ， $V$ を任意の高さ $h$ の外錐の周速度, $V_{0}$ を高さ $H$ の外錐 の周速度とすると，Fig. 6 K示すよ5に

$$
\begin{aligned}
& R_{0}=h \tan \theta_{0} \equiv h t_{0} \quad(22) \\
& R_{1}=h \tan \theta_{1} \equiv h t_{1} \quad(23)
\end{aligned}
$$

であるから，(21）式代入 すると

$$
\begin{aligned}
& d M=4 \pi V / t_{1} . \\
& \frac{t_{1}^{2} t_{0}{ }^{2}}{\left(t_{1}^{2}-t_{0}{ }^{2}\right)} h \cdot \eta \cdot d h
\end{aligned}
$$

いま, Fig. 6 К执いてて幾 何学的炡

$$
V / h=V_{0} / H
$$

であるから，(24）式は

$$
\begin{aligned}
& d M=4 \pi V_{0} / H t_{1} \cdot \\
& \quad t_{1} t_{0} t_{0} /\left(t_{1}{ }^{2}-t_{0}{ }^{2}\right) \cdot \eta \cdot h^{2} \cdot d h
\end{aligned}
$$

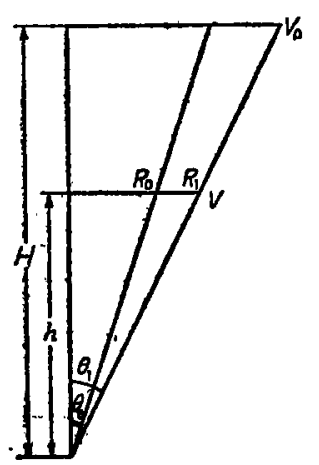

Fig. 6
（26）式を積分して

$$
M=\frac{4 \pi V_{0}}{3 H t_{1}} \cdot \frac{t_{1}{ }^{2} t_{0}{ }^{2}}{t_{1}{ }^{2}-t_{0}{ }^{2}} \cdot \eta \cdot h^{3}
$$

むし $h=H$ ならば

$$
M=\frac{4 \pi V_{0}}{3 t_{1}} \cdot \frac{t_{1}{ }^{2} t_{0}{ }^{2}}{t_{1}{ }^{2}-t_{0}{ }^{2}} \eta H^{2} \equiv A \cdot \eta \cdot H^{2}
$$

ただ $A=\frac{4 \pi V_{0}}{3 t_{1}} \cdot \frac{t_{1}{ }^{2} t_{0}{ }^{2}}{t_{1}{ }^{2}-t_{0}{ }^{2}}$

（3）モーメントの計算据り楾の挍りモーメント については，慣性能率を $I\left[\mathrm{~g} \cdot \mathrm{cm}^{2}\right]$, 周期を $T[\mathrm{sec}]$, 据れ角を $\theta$ [radian] とすれば

$$
M=-\frac{4 \pi^{2}}{T^{2}}-I \theta \quad[\text { dyne } \cdot \mathrm{cm}]
$$

が成立する。また円い棒の慣性能率については，長さを $\cdot l[\mathrm{~cm}]$, 棒の半径を $R[\mathrm{~cm}]$, 新断弾性係数を $G[\mathrm{gr} /$ $\left.\mathrm{cm} \cdot \mathrm{sec}^{2}\right]$ とすれば

$$
I=G R^{4} T^{2} / 8 \pi l
$$

\begin{tabular}{|c|c|c|c|}
\hline wire & e No. & Radius $R$ & Calculating Formula $\boldsymbol{M}$ \\
\hline & 1 & $0.015(\mathrm{~cm})$ & $M=2.92 \times 10^{3} \theta(\mathrm{dycn} \cdot \mathrm{cm})$ \\
\hline & 2 & 0.02925 & $M=4.23 \times 10^{4} \theta$ \\
\hline & 3 & 0.04625 & $M=2.64 \times 10^{5} \theta$ \\
\hline & 4 & 0.0590 & $M=6.99 \times 10^{5} \theta$ \\
\hline \multicolumn{4}{|c|}{ where: } \\
\hline \multicolumn{3}{|c|}{$\begin{array}{l}l: \text { length of torsion wire } \\
G: \text { Modulus of rigidity } \\
\theta: \text { Angle of deflection } \\
H: \text { height of inner cone } \\
t_{0}=\tan \theta_{0}=0.1364 \\
r_{0}: \text { Inner radius of outer }\end{array}$} & $\begin{array}{l}l=220(\mathrm{~cm}) \\
G=8.07 \times 10^{11}(\mathrm{~g} / \mathrm{cm} \cdot \text { sects }) \\
(R a d i a n) \\
H=14.8(\mathrm{~cm}) \\
t_{1}=\tan \theta_{1}=0.1713 \\
\text { cone at } \\
I=14.8(\mathrm{~cm}) r_{0}=2.7(\mathrm{~cm})\end{array}$ \\
\hline
\end{tabular}

が成立する。(29)，(30）両式から I を消去すると

$$
M=\pi G R^{4} \theta / 2 l
$$

が得られる。ゆえに（27）式と（3I）式を用いて，この 実験装固の恒数である $H, t_{0}, t_{1}, G, R, l$ を代入し， 一方実験によって $V_{0} ， h ， \theta$ を知れば，その夜体のその 温度に和忖る粘性保数 $\eta$ が求められる。

（4）本実験裝置における計算式外錐の回転数を $N$ [rps]，高さ $H$ の所の外錐の内径を $x_{0}[\mathrm{~cm}]$ とすると

$$
V_{0}=2 \pi r_{0} \times N
$$

と表わせるから（27）式は

$$
M=\left\{\frac{4 \pi}{3 H t_{1}} \cdot \frac{t_{1}{ }^{2} t_{0}{ }^{2}}{t_{1}{ }^{2}-t_{0}{ }^{2}} \cdot 2 \pi V_{0}\right\} \eta N h^{3}
$$

これに Table 1 脚注の桓数を代入すると

$$
\eta=\frac{M}{1.425 \cdot N \cdot h^{3}}
$$

となる。また（31）式を本実験装置について求めると， Table 1 のようになる。したがって（34）式と Table 1 により粘性係数 $\eta[\mathrm{gr} / \mathrm{cm} \cdot \mathrm{sec}]$ が求められる。

Table 1 Constants of apparatus 


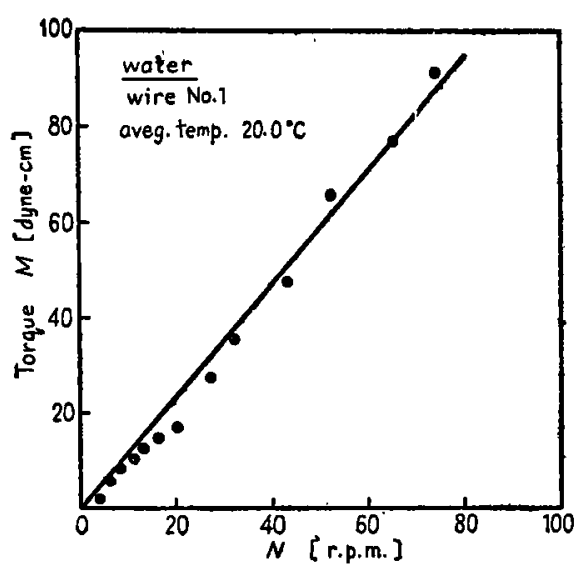

Fig. $7 M-N$ relation of water

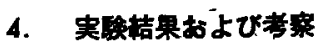

（1）理々の試料液体の $\boldsymbol{M}-\boldsymbol{N}$ (トルク対回枟数) 線 図実験した種々の試料液体の回転数に対するトルク (dyne·cm) の関俰は，それぞれの温度について Fig. 7. 8 版よ゙ Fig. 9 に示されている。実験条件として, 内錐上端玉で試料液体が入っている

a）水 Fig.7飞示すよ5に，水の場合にはデータ 一にかなりの分散が認められる。これは湘定中の温度変 化の影響とは考えられぬ分散で，むしろ低粘度夜体を回 転粘度計で測るといらことの無理，すなわち，回転によ る振動の影瑤，および試料の流動状態の变化に起因する るのと思われる。しかし他の油の例から推察して、これ を一応直楾とみなすこと仕可能である。一般に, 試料が 乱流状態になると見期けの粘性俰数は增加するが，この データからは乱流状熊になっているとは考えられない。

b）油およひ㽬脂ワニス Fig. 8 K示

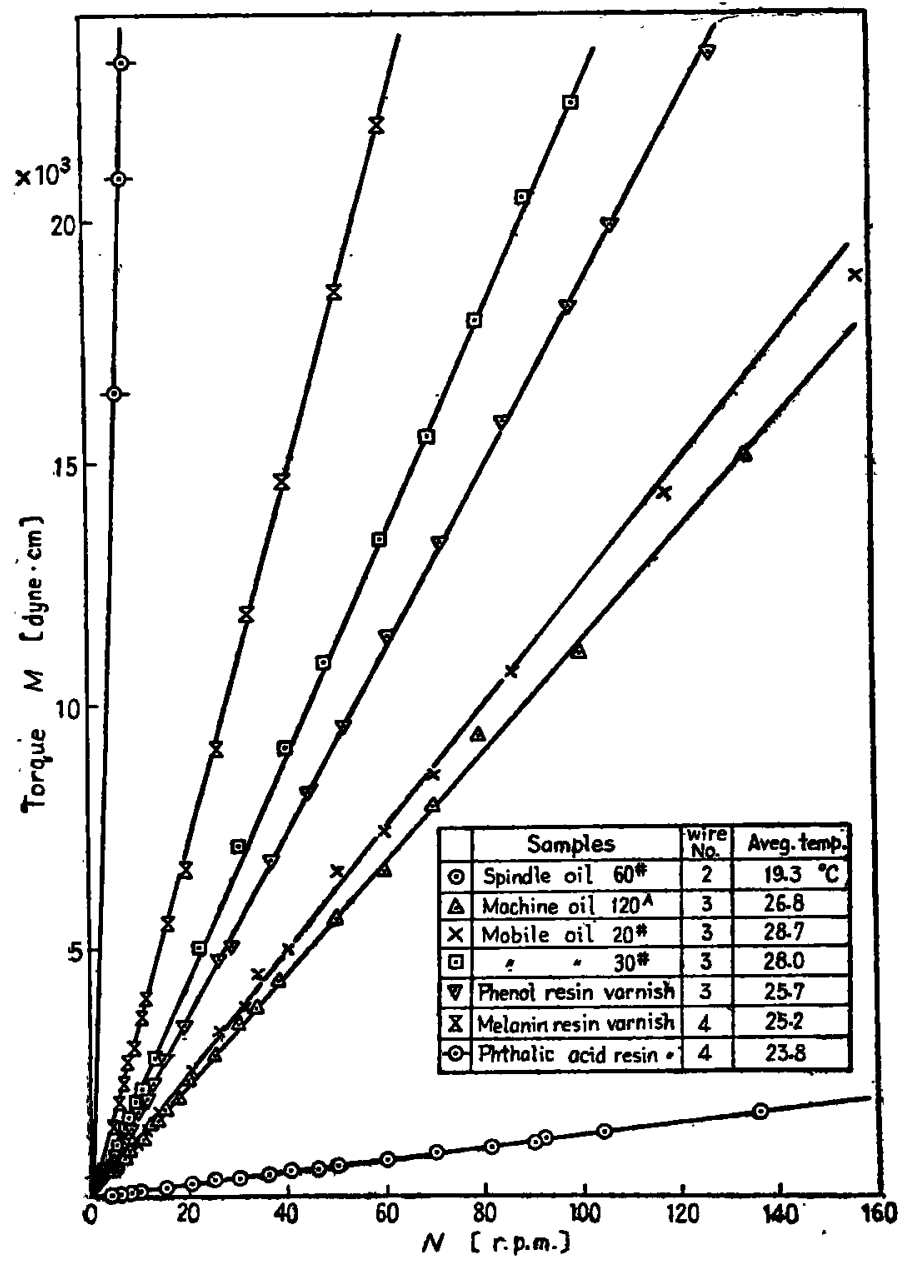

Fig. $M-N$ relations of 4 oils and 3 resin varnishes
すように，油および樹脂ワニスに対しては，

原点を通る良好な直線性を有する結果が得ら

れた。スビンドル油は比較的低粘度であるに

す拘らず，かなり大きい回転数でる流動状態

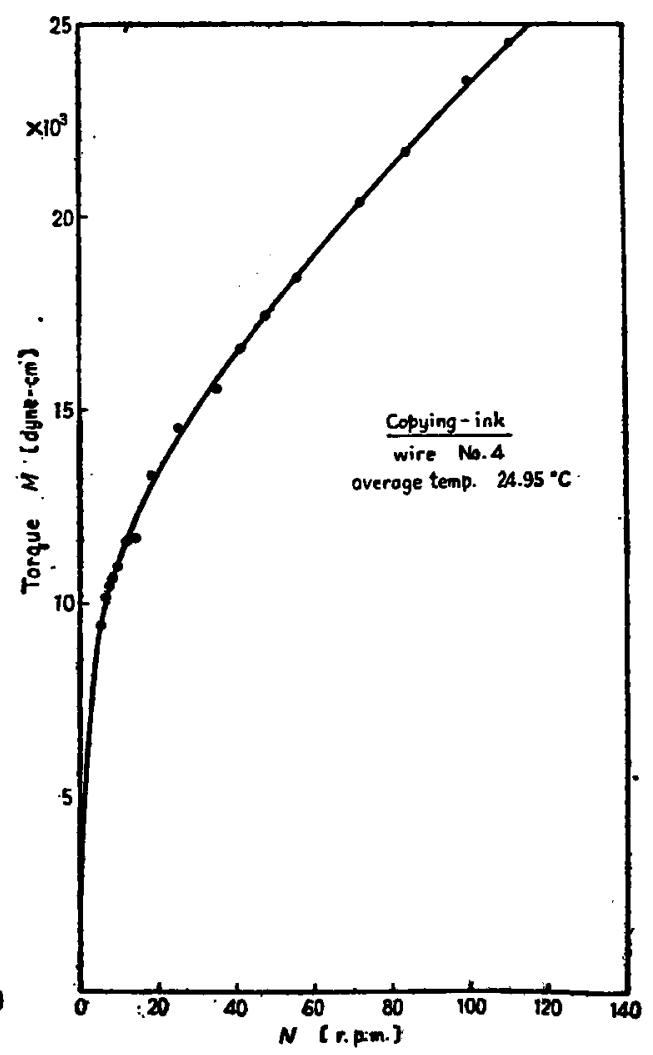

Fig. $9 \quad M-N$ relation of copying ink 
が变化しない。一般に，粘度の 上开ととるに直線性は良好とな クデータの分散はほとんどな く，再現性にすぐれている。特 K，樹脂ワニスのように高粘度 になると，全く分散が見られな い。これらの直楾性は, 試料が 完全なニュートン流体であるこ とを意味する。このことから， 本装置も一般の回転粘度計々同 様，粘度の上界ととるにそのデ 一夕の信頼性は增加するが，他 の回転粘度計に比へて, 低粘度 においてる，なおおる程度信用 できる値が得られることがわか る。

c) 滕写版用印刷インク

以上の試料はすへて $M-N$ 関係 が直線で，完全なニュートン流 体であったが，Fig.9 亿示すよ $3 \mathrm{~K}$ ，印刷用インクは $M-N$ 関

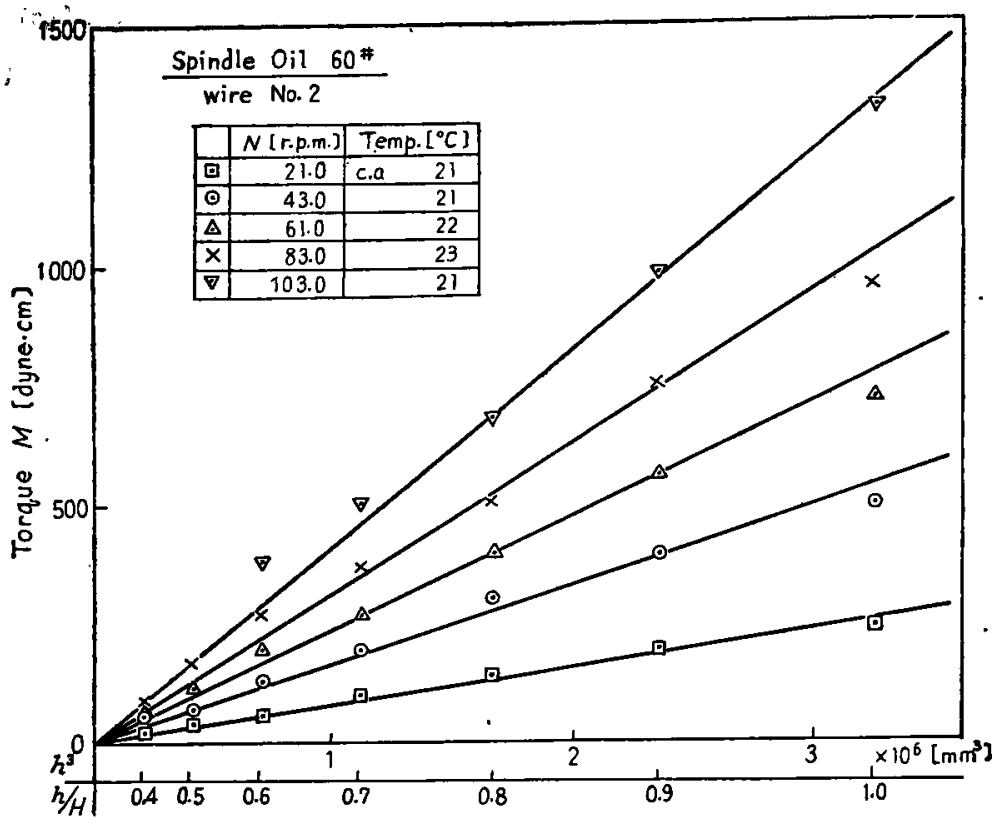

Fig. 10 Relation between torque $M$ and the depth of inner cone steeped into liquid

係が曲線となり，非ニュートン流体である。この試料に ついては, 回転数の小さいときのトルクの势化がよく表 われており，回転数の增加ととすとその変化か緩慢とな る。これは油中に分散している顔料粒か，回転数の小さ い間は互い比抵抗してトルクが大きいが，回転数が增加 すると，粒子間飞滑りが生じてトルクが比例的に增加せ

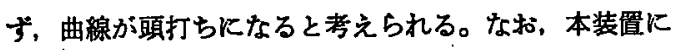
よる非ニュートン流体の測定に関しては，今後の研究に 期待するところが大きい。

（2）液深さ $h / \boldsymbol{H}$ とトルク $\boldsymbol{M}$ との関係 （27）式 からわかるよ5に, トルク $M$ は液深さ $h$ の三乗に比例 しなければならない。ゆえに，一定回転数，一定温度で

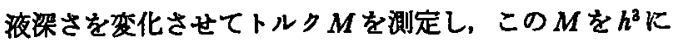
つい plot したのが Fig. 10 である。この図から、デ 一タに多少の分散はむるが，いずれの回転数の場合につ いても原点 0 を通る放射状の直線にまとめられる。した がって, $M$ は $h^{3}$ 飞比例する理論的関保か実験で証明さ れたわけである。Fig.10 に示されたデータは，種タの 回転数についてほとんど同じ温度で測定されているの で,これを $h / H$ を parameter として $M-N$ 線図に示し

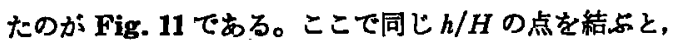
いずれす，原点 0 を通る放射状の直湶になることがかか る。いまある回転数のときの $h / H=1$ のトルク $M$ の 值を用いて (34) 式で $h / H$ を变化させて得た $M$ の計算 值と，Fig. 11 と示されたそれぞれの $h / H$ のところの実

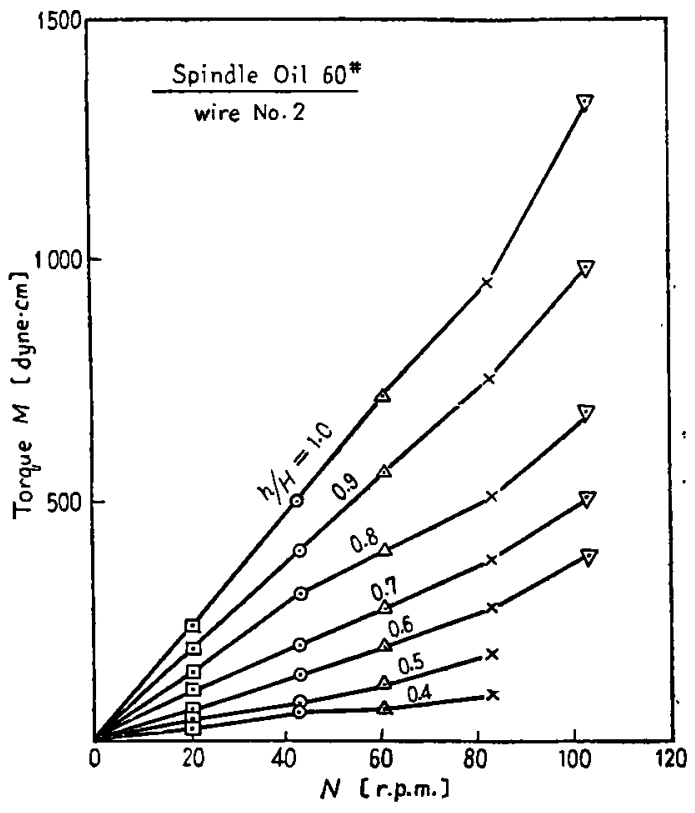

Fig. $11 \quad M-N$ relation of spindle oil 60 in terms of $h / H$ as its parameter

験値を比較してみると、Table 2のようになる。したが ってこの性筫から, 陚料の非常に少ないとき，または $h$ $=H$ まで試料を入れるとその torsion wire では粘性が 高くて scale up するような場合，液高さを加減して測 
定すれい゙同様に正確な值が得られるといらことになり。 torsion wire を变えずに測定できる。

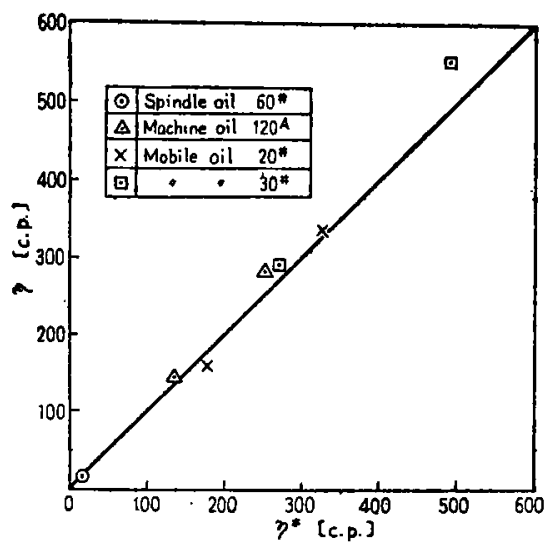

Fig. $12 \quad \eta-\eta *$ relation for 4 oils

Table 2

Comparison of the calculated value by Eq. (34) with the experimental value obtained when the measurement was taken at $h / H$

\begin{tabular}{ccc}
$h / H$ & $\begin{array}{c}\text { Calculated value } \\
\text { (dyne.cm) }\end{array}$ & $\begin{array}{c}\text { Experimental data } \\
\text { (dyne-cm) }\end{array}$ \\
\hdashline 1.0 & 720.0 & 720.0 \\
0.9 & 522.0 & 560.0 \\
0.8 & 369.0 & 393.5 \\
0.7 & 247.0 & 270.5 \\
0.6 & 155.4 & 196.5 \\
0.5 & 90.0 & 117.0 \\
0.4 & 46.1 & 67.6 \\
where: $\quad N=61$ (rpm)=1.017 (rps) \\
\end{tabular}

Table 3

Comparison of the experimental data on the capacity of this cone type rotational viscometer with those on the capacity of other viscometers

\begin{tabular}{|c|c|c|c|}
\hline Samples & $\begin{array}{l}\text { Tempe- } \\
\text { rature } \\
\left({ }^{\circ} \mathrm{C}\right)\end{array}$ & $\begin{array}{l}\text { Viscosity mea- } \\
\text { sured with cone } \\
\text { type }(\eta) \text { (c.p.) }\end{array}$ & $\begin{array}{l}\text { Viscosity }\left(\eta^{*}\right) \text { mea- } \\
\text { sured with by ost- } \\
\text { wald \& B type(c.p.) }\end{array}$ \\
\hline Water & 20.0 & 1.556 & 1.005 \\
\hline $\begin{array}{l}\text { Spindle oil } \\
60 *\end{array}$ & $\begin{array}{l}19.30 \\
19.35\end{array}$ & $\begin{array}{l}16.1 \\
16.0\end{array}$ & $\begin{array}{l}\mathrm{O} \\
\mathrm{O} \\
16.40\end{array}$ \\
\hline $\begin{array}{c}\text { Machine oil } \\
120 \mathrm{~A}\end{array}$ & $\begin{array}{l}17.95 \\
26.80\end{array}$ & $\begin{array}{l}282.5 \\
146.5\end{array}$ & o $\begin{array}{r}249.0 \\
133.0\end{array}$ \\
\hline $\begin{array}{c}\text { Mobile oil } \\
\text { 20ł }\end{array}$ & $\begin{array}{l}19.50 \\
28.70\end{array}$ & $\begin{array}{l}335.5 \\
160.0\end{array}$ & $\begin{array}{l}\text { B } 323.0 \\
\text { B } 374.0\end{array}$ \\
\hline $\begin{array}{l}\text { Mobile oil } \\
30 \sharp\end{array}$ & $\begin{array}{l}19.85 \\
28.00\end{array}$ & $\begin{array}{l}553.0 \\
291.0\end{array}$ & B $\begin{array}{r}490.0 \\
258.0\end{array}$ \\
\hline Phenol resin & 25.65 & 240.5 & \\
\hline Melanin resin & 25.20 & 467.0 & \\
\hline $\begin{array}{l}\text { Phthalic acid } \\
\text { resin }\end{array}$ & 23.75 & 3300.0 & \\
\hline
\end{tabular}

（3） End effect 本装置の殾計目的の一つはこの end effect を除去することであり，このために円雓を探 用したのであるが（2）でのへたようK，Mは $h^{2}$ K比 例することが実証され，Fig. 10の上うに，いずれの線す 原点を通る故射状の直線で示されることは，この䈯が end effect K関しては初期の設計目的を满足しているこ とを示している。しかし液梁さの影翠に関しては、さら に多くの実驗を必要とする。

\section{（4）本粘度計と他の粘度計による結果との比較}

Fig. 8 で示された $M-N$ 線図は直線で示されるから，任 意の回転数 $N$ K対するトルク $M$ を求め, これを (34) 式に代入すれ《は粘性係数 $\eta[\mathrm{gr} / \mathrm{cm} \cdot \mathrm{sec}]$ が求められる。 これと別に比較の目的で, 他の粘度計（低粘度は Ostwald 粘度計, 高粘度は B 型回転粘度計)により同し試 料液体の粘度を湘定した。これを Table 3 k示す。

この表から，水に関しては約 50\%の差異を生している か，元来水の上5な低粘度のるのを回転粘度計で測定す ること自体が雅問で，ここには低粘度の例として取り上 け゚たにすきない。しかし，市肘のB 型回転粘度計などで 测ったるのよりは良好な結果を得ている（B 型回転粘度 計では，水は4 6c.p. 济测定される)。

また，他の油については，Ostwald 粘度計で測定した 值はかなり信頼性があるので，本装固の値との差は一応 誤差と考えられるが，B型回転粘度計の值はそれ自体が 不正確なため，本畒の值との差を誤差として扱らこと はできないむむし本装置の值の方が再現性があり信頼 性が大きい。Fig. 12 に本装眉の值と Ostwald および B 型回転粘度計で测定した値との関係を示す。

しかしながら、ここに生じた差異は，工業上から考え れば充分許しらると考えられるので，本装置は充分実用 される。この羑異の原因としては

i）実験の初めと終りにおける温度変化

ii）周期運動をする目盛の読みの誤差

iii）振動による拫れの不均衡, 風に上る掋れ誤差 などが考えられる。

\section{5. 結 言}

回転型粘度計の end effect 艺除く目的で, 同心同頂点 円錐を用いた外筒回転型粘度計を試作し，理論值と実験 值を比較したところ，かなりよい一致を見ることができ た。また極く小さい回転数で实験することにより、トル ク対回転数線図 $(M-N$ 線図) は原点を通ることが確め られ. end effect が完全に除去されていることがわかっ た。またこの粘度計による測定は安定性，再現性にすく れ，低粘度においててす他の回転型粘度計飞比へて，比較 的正確な測定値を得ることができる。るちろん高粘度に 
なるにしたがって测定値の分散す少なくなり、ニニート ン流体火対しては $M-N$ 線図は完全な直楾にのることが わかった。この粘度計はまた，低速域での測定が適確炕 行われ，非ニニートン流体の測定にす適するすのと思わ れる。

\section{Nomenclature used}

$\boldsymbol{R}_{0}$ : radius of inner cylinder at $h$

$R_{1}$ : radius of outer cylinder at $h$ [cm]

$v_{R 1}(=V):$ peripheral velocity of outer cylinder

$[\mathrm{cm} / \mathrm{sec}]$

$N$ : revolution number of outer cylinder [rpm]

$v$ : peripheral velocity of liquid at a distance of $r$ from center $\quad[\mathrm{cm} / \mathrm{sec}]$

$w$ : angular velocity of liquid at a distance of $r$ from center

$[1 / \mathrm{sec}]$

$r$ : distance from center of cone

$$
\begin{aligned}
M & : \text { torque } \\
h & : \text { depth of sample liquid } \\
\tau: & \text { shearing stress } \\
r: & \text { shearing strain } \\
\eta & : \text { coefficient of viscosity } \\
\theta_{0}, \theta_{1} & : \text { half top angle of inner and } \\
& \text { outer cone }
\end{aligned}
$$

[dyne $\cdot \mathrm{cm}]$

[cm]

$\left[\mathrm{gr} / \mathrm{cm} \cdot \mathrm{sec}^{2}\right]$

[一]

$[\mathrm{gr} / \mathrm{cm} \cdot \mathrm{sec}]$

[degree]

[cm]

$H$ : height of inner cone

$[\mathrm{cm} / \mathrm{sec}]$ at $H$

$\left[\mathrm{gr} \cdot \mathrm{cm}^{2}\right]$

$I$ : moment of inertia

[sec]

$T:$ period of oscillation

[radian]

$\theta$ : angle of deflection

[cm]

$l$ : length of torsion wire

[cm]

$R$ : radius of torsion wire

$\left[\mathrm{gr} / \mathrm{cm} \cdot \mathrm{sec}^{2}\right]$

$G$ : modulus of rigidity

[cm]

\title{
Studies on the Cone Type Rotational Viscometer
}

\author{
Y. Nakagawa, ${ }^{*}$ S. Okuda, ${ }^{*}$ H. Shihō, ${ }^{* *}$ S. Yoshimura*
}

In order to eliminate the end effect of the ordinary rotational viscometer, we designed a new viscometer which was constructed of a conical vessel with a concentrically situated inner cone as shown in Fig. I. The outer cone was rotated by a motor. By comparing the experimental data on the operation of this viscometer with the theoretically calculated values, we obtained a good stable agreement between the two. By means of this viscometer, we were able to measure more accurately even low viscosity as well as high viscosity than by any other rotational viscometer.

The experimental apparatus is shown in Fig. 2. A general equation for the torque of the rotational viscometer (with outer cylinder rotated) may be expressed with the aid of Eqs. (3), (4) and (5) as in Eq. (21). From this, a theoretical equation for the cone type rotational viscometer may be derived using Fig. 6, which will be expressed as shown in Eq. (28).

By introducing the constants of this apparatus, $\left(t_{1}, t_{0}, H, r_{0}\right)$ and $(h, M, N)$ into Eq. (28), we obtained the coefficient of viscosity $\eta$ of the sample liquid. Eq.(31) shows the relation between the moment $M$ and the angle of deflection $\theta$ of torsion wire.

The experimental data are shown in Figs. 7, 8 and 9 . In Figs. 7 and 8, we find the sample liquids having the quality of the Newtonian liquid, and the data represented by linear lines through the origin. As seen from these results, the end effect was completely eliminated from this apparatus, and the experimental data obtained with it were well ordered and had good reproductivity.

Fig. 10 shows the relation between torque $M$ and the dipped height of the inner cone into liquid, it having been proved that $M$ is proportional to $h^{3}$ and that there is a good agreement between Eq. (33) and the experimental results.

The comparison of the experimental data on this cone type rotational viscometer and those of the other viscometers is shown in Fig. 12. For water, the difference between the two was about $50 \%$. It may be considered somewhat greater than ususal, but such is common with ordinary viscometers. The data on other oils and resin varnishes obtained with this viscometer were approximately equal to those obtained with other viscometers, measurements being always stable and having good reproductivity.

* Department of Chemical Engineering. Kyoto University

* Nippon Paint Co. Itt. 